\title{
GLI3 wt Allele
}

National Cancer Institute

\section{Source}

National Cancer Institute. GLI3 wt Allele. NCI Thesaurus. Code C52927.

Human GLI3 wild-type allele is located in the vicinity of $7 p 13$ and is approximately $272 \mathrm{~kb}$ in length. This allele, which encodes zinc finger protein GLI3, plays a role in the regulation of sonic hedgehog-dependent transcription of specific genes during the development of multiple organ systems. This gene is the site of a mutation that is linked to Greig cephalopolysyndactyly syndrome. 